\title{
Genotyping of $\beta$-Lactoglobulin gene by PCR-RFLP in Sahiwal and Tharparkar cattle breeds
}

\author{
Satyanarayana Rachagani ${ }^{1}$, Ishwar Dayal Gupta*1, Neelam Gupta ${ }^{2}$ and \\ SC Gupta ${ }^{2}$
}

Address: ${ }^{1}$ Animal Genetics and Breeding, Dairy Cattle Breeding Division, National Dairy Research Institute, Karnal, Haryana-132001, India and 2DNA Fingerprinting Unit, National Bureau of Animal Genetic Resources, Baldy Bypass, Karnal, Haryana-132001, India

Email: Satyanarayana Rachagani - satyarachagani@rediffmail.com; Ishwar Dayal Gupta* - idgdcb59@yahoo.co.in; Neelam Gupta - neelamg@nbagr.ernet.in; SC Gupta - scgupta@nbagr.ernet.in

* Corresponding author

Published: 25 May 2006

BMC Genetics 2006, 7:31 doi:10.1186/147|-2156-7-31
Received: 02 September 2005

Accepted: 25 May 2006

This article is available from: http://www.biomedcentral.com/|47|-2/56/7/3I

(C) 2006 Rachagani et al; licensee BioMed Central Ltd.

This is an Open Access article distributed under the terms of the Creative Commons Attribution License (http://creativecommons.org/licenses/by/2.0), which permits unrestricted use, distribution, and reproduction in any medium, provided the original work is properly cited.

\begin{abstract}
Background: Improvement of efficiency and economic returns is an important goal in dairy farming, as in any agricultural enterprise. The primary goal of dairy industry has been to identify an efficient and economical way of increasing milk production and its constituents without increasing the size of the dairy herd. Selection of animals with desirable genotypes and mating them to produce the next generation has been the basis of livestock improvement and this would continue to remain the same in the coming years. The use of polymorphic genes as detectable molecular markers is a promising alternative to the current methods of trait selection once these genes are proven to be associated with traits of interest in animals. The point mutations in exon IV of bovine $\beta$-Lactoglobulin gene determine two allelic variants $A$ and $B$. These variants were distinguished by Polymerase Chain Reaction and Restriction Fragment Length Polymorphism (PCR-RFLP) analysis in two indigenous Bos indicus breeds viz. Sahiwal and Tharparkar cattle. DNA samples (228 in Sahiwal and 86 in Tharparkar) were analyzed for allelic variants of $\beta$-Lactoglobulin gene. Polymorphism was detected by digestion of PCR amplified products with Hae III enzyme, and separation on $12 \%$ non-denaturing gels and resolved by silver staining.
\end{abstract}

Results: The allele $B$ of $\beta$-Lactoglobulin occurred at a higher frequency than the allele $A$ in both Sahiwal and Tharparkar breeds. The genotypic frequencies of $A A, A B$, and $B B$ in Sahiwal and Tharparkar breeds were $0.031,0.276,0.693$ and $0.023,0.733,0.244$ respectively. Frequencies of $A$ and $B$ alleles were 0.17 and 0.83 , and 0.39 and 0.61 in Sahiwal and Tharparkar breeds respectively. The Chi-square test results (at one degree of freedom at one per cent level) revealed that the Tharparkar population was not in Hardy-Weinberg equilibrium as there was a continuous migration of animals in the herd studied, where as, the results are not significant for the Sahiwal population.

Conclusion: Genotype frequencies of AA were the lowest compared to that of BB genotype in Sahiwal cattle while $A B$ genotypes were more frequent in Tharparkar cattle. The frequency of $A$ allele was found to be lower than that of $B$ allele in both the breeds studied. These results further confirm that Bos indicus cattle are predominantly of $\beta$-Lactoglobulin B type than Bos taurus breeds. 
Table I: Fragment size corresponding to different $\beta$-lactoglobulin genotypes after digestion of a 252 bp PCR product with Hae III restriction enzyme.

\begin{tabular}{llll}
\hline Genotype & $\begin{array}{l}\text { Fragment size after digestion with Hae III } \\
\text { restriction enzyme }\end{array}$ & No. of genotypes & \\
\hline Uncut PCR Product & 252 bp & Sahiwal $(\mathbf{n}=\mathbf{2 2 8})$ & Tharparkar (n= 86) \\
\hline A/A & 144 bp and 108 bp & 7 & 2 \\
A/B & 144 bp, 108 bp, 74 bp and 70 bp & 63 & 63 \\
B/B & 108 bp, 74 bp and 70 bp & 158 & 21 \\
\hline
\end{tabular}

\section{Background}

Milk protein genetic polymorphism has received considerable research interest in recent years because of possible associations between milk protein genotypes and economically important traits in dairy cattle. Many research reports have indicated that certain milk protein variants may be associated with milk production [1-4], milk composition [5-15] and cheese production [5,6,12-14,16-20]. Therefore, milk protein genes could be useful as genetic markers for additional selection criteria in dairy cattle breeding. $\beta$-Lactoglobulin was the first protein in which polymorphism was detected. By paper electrophoresis two distinct bands of $\beta$-Lactoglobulin were observed, and named as $\beta_{1}$ and $\beta_{2}$ (A \& B) [21]. Until now at least 12 variants are known for $\beta$-Lactoglobulin, out of which $A$ and $B$ variants are more frequent. $\beta$-Lactoglobulin is the major whey protein in milk of cows and other ruminants e.g. deer, bison and buffalo, and in some non-ruminants such as pigs, horses, dogs, dolphins and whales. However, it is not an endogenous part in human milk.

$\beta$-Lactoglobulin is amphiphatic and an extremely acid stable protein which exists at the normal $\mathrm{pH}$ of bovine milk as a dimer with a molecular weight of 36,000 Daltons. It is a single chain polypeptide of $18 \mathrm{kDa}$ comprising of 162 amino acid residues. The complete amino acid sequence of $\beta$-Lactoglobulin has been reported and genetic variation in amino acids sequence has been identified [22]. The bovine $\beta$-Lactoglobulin A variant differs from B variant by two amino acids only i.e. aspartate- 64 and valine118. These amino acids are substituted by glycine and alanine respectively in the B variant. All the variants contain five cysteine residues, four of which are involved in forming intra-chain disulphide bridges. The biological functions of this protein are still not known. It could have a role in metabolism of phosphate in the mammary gland and the transport of retinol and fatty acids in the gut [12]. Sahiwal and Tharparkar cattle are the best dairy breeds in the Indian subcontinent. The major breeding tracts of Sahiwal lie in Montgomery district of Pakistan and in the Indian states of Punjab and Haryana. The color ranges from reddish brown to a more predominant red, with varying amounts of white on the neck, and the underline. In males, the color darkens towards the extremities, such as the head, legs and tail. The typical Tharparkar cattle are found in the areas of Umarkot, Naukot, Dhoro Naro, Chhor, Mithi, Islamkot and Khari Ghulam Shah of Pakistan and also in the adjoining Indian States of Rajasthan and Gujarat. The usual color of the cattle is white or gray. Tharparkar are of the lyre horned type of zebu cattle. The present study aims at genotyping the two Bos indicus breeds viz. Sahiwal and Tharparkar for $\beta$-Lactoglobulin gene.

\section{Results and discussion}

The restriction digestion of $252 \mathrm{bp}$ PCR product with Hae III enzyme revealed three genotypes $\mathrm{AA}, \mathrm{AB}$ and $\mathrm{BB}$ (Figure 1). The fragment size of different genotypes is shown in Table 1. The genotypic frequencies of $\mathrm{AA}, \mathrm{AB}$, and $\mathrm{BB}$ were $0.031,0.276$, and 0.693 in Sahiwal, and 0.023, 0.733 , and 0.244 in Tharparkar respectively. In Sahiwal, the genotype frequencies of $\mathrm{BB}$ were the highest while in Tharparkar cattle the $\mathrm{AB}$ genotypes were more frequent. These results also show that the chosen primers are adequate to amplify the sequence of $\beta$-Lactoglobulin gene exon IV in Bos indicus cattle. Gene frequencies of A and B alleles were 0.17 and 0.83 in Sahiwal, and 0.39 and 0.61 in Tharparkar respectively (Table 2). The frequency of A allele was found to be lower than that of the $\mathrm{B}$ allele in both the breeds studied, and in close agreement to the results of earlier workers in Bos taurus [23] and Bos indicus [24]. The genotyping results of Sahiwal and Tharparkar breeds are similar to those reported in Gyr, Nelore and Sindi cattle [25]. Polymorphism studies conducted in dual purpose Gyr and Nelore breeds showed higher frequencies of $B$ allele than beef breeds [26]. However, AB genotype was more frequent in Tharparkar cattle. These results further confirm that Bos indicus cattle are predominantly of $\beta$-Lactoglobulin B type as compared to Bos taurus cattle. The Chi-square test results (at one degree of freedom at one per cent level) are presented in Table 2 revealing genetic equilibrium in Sahiwal cattle. In Tharparkar, the Chi-square test revealed that the Tharparkar population was not in Hardy-Weinberg equilibrium as there was a continuous migration of animals in the herd studied. 
Table 2: Gene and genotypic frequencies of $\beta$-Lactoglobulin gene determined by PCR-RFLP in Sahiwal and Tharparkar breeds.

\begin{tabular}{|c|c|c|c|c|c|c|c|c|}
\hline \multirow[t]{2}{*}{ Breed } & \multirow[t]{2}{*}{ No. of animals } & \multirow{2}{*}{$\begin{array}{l}\text { Chi-square test (one } \\
\text { degree of freedom) }\end{array}$} & \multicolumn{3}{|c|}{ Gene frequency } & \multicolumn{3}{|c|}{ Genotype frequency } \\
\hline & & & A & B & SD & AA & $\mathbf{A B}$ & BB \\
\hline Sahiwal & 228 & $0.03^{\mathrm{NS}}$ & 0.17 & 0.83 & 0.025 & 0.031 & 0.276 & 0.693 \\
\hline Tharparkar & 86 & $25.0 * * *$ & 0.39 & 0.61 & 0.052 & 0.023 & 0.733 & 0.244 \\
\hline
\end{tabular}

Note: NS: Not significant; *** $\mathrm{P}<0.000$ I (one degree of freedom)

\section{Conclusion}

The frequencies of AA genotype was the lowest while that of $\mathrm{BB}$ genotype highest in Sahiwal cattle whereas the AB genotypes were more frequent in Tharparkar animals. Frequency of A allele was found to be lower than that of B allele in both the breeds studied.

\section{Methods}

Blood samples were collected in vacutainers (BactonDickinson vacutainer system) containing sodium EDTA as an anticoagulant from 228 Sahiwal and 86 Tharparkar cattle breeds maintained at National Dairy Research Institute, India. Genomic DNA was extracted using phenol chloroform method from $10 \mathrm{ml}$ of whole blood [27] and semen [28]. The quality of DNA was checked on $0.6 \%$

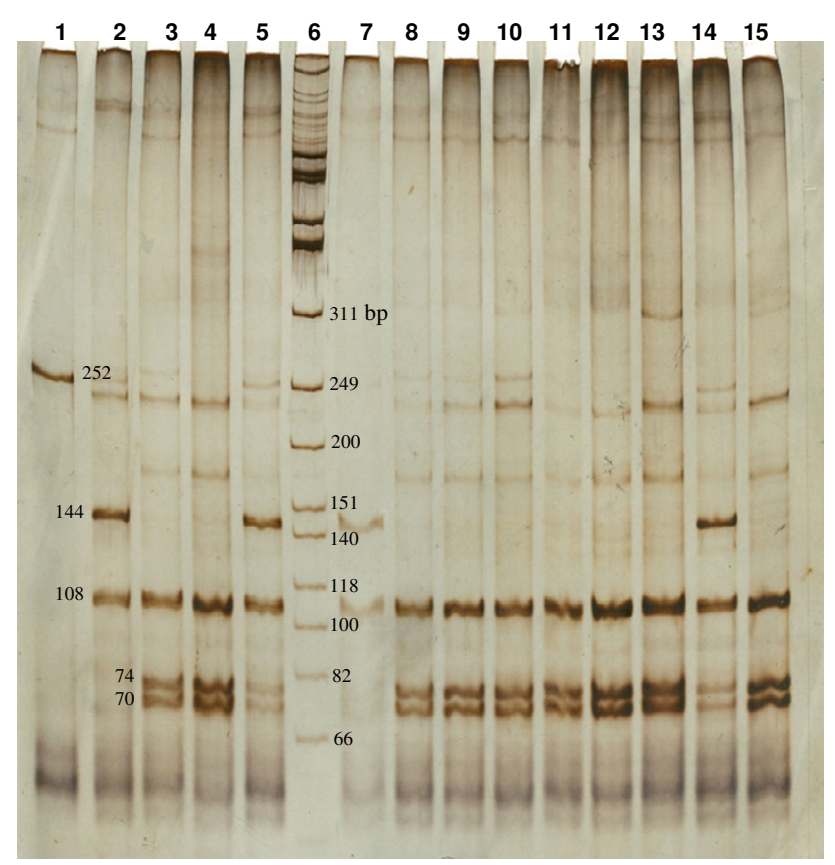

\section{Figure I}

PCR-RFLP of $\beta$-lactoglobulin gene polymorphism using Hae III restriction endonuclease enzyme in Sahiwal cattle. Lane I: PCR product, Lane 2 and 7: AA, Lane 3, 4, 8-13 and I5: BB, Lane 5 and I4: AB and Lane 6 ladder: $\Phi \times 174$ Hinf I digest. agarose and quantity by UV spectrophotometer at $\mathrm{A}_{260} /$ $\mathrm{A}_{280} \mathrm{~nm}$. The samples having OD ratio between 1.7-1.9 were considered good, and used for polymerase chain reaction.

The sequences of primers [29] used for amplification of exon IV of $\beta$-Lactoglobulin gene containing polymorphic sites for A and B alleles were: 5'-GTC CTT GTG CTG GAC ACC GAC TAC A-3' (forward) and 5'CAG GAC ACC GGC TCC CGG TAT ATG A-3' (reverse). The PCR amplification reaction contained $100 \mathrm{ng}$ DNA, $50 \mathrm{ng} / \mu \mathrm{l}$ of each primer, $1.5 \mathrm{mM}$ of $\mathrm{MgCl}_{2}, 100 \mu \mathrm{M}$ of dNTPs, PCR buffer $(10 \mathrm{mM}$ $\mathrm{KCl}, 10 \mathrm{mM}\left(\mathrm{NH}_{4}\right)_{2} \mathrm{SO}_{4}, 20 \mathrm{mM}$ Tris- $\mathrm{HCl}, 2 \mathrm{mM} \mathrm{MgSO}{ }_{4}$, $0.1 \%$ TritonX-100, pH 8.8) and 0.7 units of Taq DNA polymerase. The fragment was amplified by hot start PCR, in which $2 \mu \mathrm{l}$ of genomic DNA and $1.5 \mu \mathrm{l}$ of Tris $(20 \mathrm{mM})$ were placed in a PCR tube overlain with a thin layer of mineral oil. The PCR amplification was carried out in a programmable thermal cycler (MJ research) using the following program: denaturation at $95^{\circ} \mathrm{C}$ for 5 minutes, the temperature lowered to $85^{\circ} \mathrm{C}$ and PCR master mix added at the top of the mineral oil. The PCR was as follows: 3 minutes at $97^{\circ} \mathrm{C}, 1$ minute at $60^{\circ} \mathrm{C}, 1$ minute at $72^{\circ} \mathrm{C}$ followed by 34 cycles of 1 minute at $94^{\circ} \mathrm{C}, 1$ minute at $60^{\circ} \mathrm{C}$ and 1 minute at $72^{\circ} \mathrm{C}$ and a final extension of 10 minutes at $72^{\circ} \mathrm{C}$. The PCR products were loaded on $1.5 \%$ agarose to confirm the amplification of target region using $\Phi \times$ $174 \operatorname{Hinf}$ I digest as a marker. The restriction digestion of the PCR products were carried out with Hae III enzyme [29] with few modifications: the PCR products were subjected to digestion by restriction enzymes in a total volume of $25 \mu \mathrm{l}$. The reaction was set up with $5.00 \mu \mathrm{l}$ of ddH20, $2.5 \mu$ l of restriction endonuclease buffer 2 (New England Biolabs), 3.6 units of Hae III and $17.0 \mu$ of PCR product, and incubated at $37^{\circ} \mathrm{C}$ for about 3 hours. The reaction was stopped by adding $0.5 \mathrm{M}$ EDTA to a final concentration of $10 \mathrm{mM}$. The restriction digested fragments were separated on $12 \%$ non-denaturing gels using PROTEAN II xi cell (Bio-rad, USA) at $4 \mathrm{v} / \mathrm{cm}$ for about 6 hours. The gels were stained by silver staining [30] and the three genotypes $\mathrm{AA}, \mathrm{AB}$ and $\mathrm{BB}$ scored manually. Chisquere test [31] was conducted to test the population for Hardy-Weinberg equilibrium. 


\section{Authors' contributions}

RS carried out molecular genetics studies, statistical analysis and drafted the manuscript.

IDG was responsible for conceived the study, concept, designed, coordinated the study and corrected the manuscript.

NG and SCG provided their laboratory facilities for carrying out experimental work.

\section{All authors have read and approved the final manuscript}

\section{Acknowledgements}

The authors thank the National Dairy Research Institute, Karnal for funding the project and National Bureau of Animal Genetic Resource, Karnal for providing the facilities. The authors are thankful to Lydia, D.C. for proof reading the manuscript.

\section{References}

I. Ng-Kwai-Hang KF, Hayes JE, Moxley JD, Monardes HG: Association of genetic variants of casein and milk serum protein with milk fat and protein production in dairy cattle. Journal of Dairy Science 1984, 67:835-40.

2. Gonyon DS, Mather RE, Hines HC, Haenlein CFW, Arave CW, Gaunt $\mathrm{SN}$ : Association of bovine blood and milk polymorphism with lactation traits in Holstein. Journal of Dairy Science 1987, 70:2585-2598

3. Haenlein CFW, Gonyon DS, Mather RE, Hines HC: Association of bovine blood and milk polymorphism with lactation traits in Guernsey. Journal of Dairy Science 1987, 70:2599-2609.

4. Bech AM, Kristiansen KR: Milk protein polymorphism in Danish dairy cattle and the influence of genetic variants on milk yield. Journal of Dairy Science 1990, 57:53-63.

5. Mclean DM: Influence of milk protein genetic variants on milk composition, yield and cheese making properties. Animal Genetics 1987:100-1002.

6. Mclean DW, Schaar J: Effects of beta lactoglobulin and kappa casein genetic variants and concentration on synthesis of gels from renneted heated milk. Journal of Dairy Research 1989, 56:297-30I.

7. Lin CY, McAllister AJ, Ng-Kwai-Hang KF, Hayes JF: Effects of milk protein loci on first lactation production in dairy cattle. Journal of Dairy Science 1986, 69:704-712.

8. Ng-Kwai-Hang KF, Hayes JF, Moxley JD, Monardes HG: Relationship between milk protein polymorphism and major milk constituents in Holstein-Friesian cows. Journal of Dairy Science 1986, 69:22-26.

9. Aleandri R, Buttazzoni LG, Schneider JC, Caroli A, Davoli R: The effects of milk protein polymorphism on milk components and cheese producing ability. Journal of Dairy Science 1990, 73:24I-255.

10. Eenennaam AV, Medrano JF: Milk protein polymorphism in California dairy cattle. Journal of Dairy Science 1991, 74:1730-I742.

II. Bovenhuis H, Van Arendonk JAM, Korver S: Associations between milk protein polymorphism and milk production traits. Journal of Dairy Science 1992, 72:2549-2559.

12. Hill JP, Thresher WC, Boland MJ, Creamer LK, Anema SG, Manderson G, Otter DE, Paterson GR, Howe R, Burr RG, Motion RL, Windelman A, Wickham B: The polymorphism of the milk protein $\beta$-lactoglobulin. In Milk composition, production and biotechnology Edited by: Welch RAS, et al. CAB International, Wallingford: UK; 1997:173-213

13. Lunden A, Nisson M, Janson L: Marked effect of $\beta$-Lactoglobulin polymorphism on the ratio of casein to total protein in milk. Journal of Dairy Science 1997, 80:2996-3005.

14. $\mathrm{Ng}-\mathrm{K}$ wai-Hang KF: Genetic polymorphism of milk proteins: relationship with production traits, milk composition and technological properties. Canadian Journal of Animal Science |998:|3|-|47.
15. Robitaille G, Britten M, Morisset J, Petitclerc D: Quantitative analysis of $\beta$-Lactoglobulin $A$ and $B$ genetic variants in milk of cows $\beta$-Lactoglobulin AB throughout lactation. Journal of Dairy Research 2002, 69:65I-654.

16. Schaar J, Hansson B, Petterson HE: Effect of genetic variants of kcasein and $\beta$-lactoglobulin on cheese making. Journal of Dairy Science 1985, 52:429-437.

17. Marziali AS, Ng-Kwai-Hang KF: Relationship between milk protein polymorphism and cheese yielding capacity. Journal of Dairy Science 1986, 69: I 193-1201.

18. Aaltonen ML, Antila V: Milk renneting properties and genetic variants of proteins. Milchwissenschaft 1987, 42(8):490-92.

19. Grosclaude F: Genetic polymorphism of the principal milk proteins in cattle. Relation with quantity, composition and cheese making suitability of milk. INRA Productions Animales I:5. Journal of Dairy Science 1988, 74:I730-I742.

20. Van den berg G, Escher JTM, De Koning PJ, Bovenhuis M: Genetic polymorphism of $\kappa$-casein and $\beta$-lactoglobulin in relation to milk composition and processing properties. Netherlands Milk Dairy Journal 1992, 46: |45-68.

21. Aschaffenburg R, Drewry J: Occurrence of different $\beta$-lactoglobulins in cow's milk. Nature 1955, 176:218-219.

22. Creamer L, Parry D, Malcolm G: Secondary structure of $\beta$-lactoglobulin B. Archives of Biochemistry and Biophysics 1983, 227:98-105.

23. Chung ER, Kim WT, Lee CS: The DNA polymorphism of Kappa casein and beta-lactoglobulin, growth hormone and prolactin genes in Korean cattle. Asian Australian Journal of Animal Science 1998, I I:422-427.

24. Badola S, Battacharya TK, Biswas TK, Sivakumar BM, Pushpendra Kumar, Arjava Sharma: A comparison on polymorphism of beta-lactoglobulin gene in Bos indicus, Bos taurus and indicine $\times$ taurine crossbred cattle. Asian Australian Journal of Animal Science 2004, I 7(6):733-736.

25. Del Lama SN, Zago MA: Identification for the kappa-caesin and beta-actoglobulin genotypes in Brazilian Bos indicus and Bubalis bubalis population. Brazilian Journal of Genetics 1996, 19:73-77.

26. Kemenes PA, Regitano LCA, Rosa AJML, Packer IU, Razook AG, Figueiredo LA, Silba NA, Etchegaray MAL, Coutinho LL: Kappa casein, Beta-lactoglobulin and growth hormone allele frequencies and genetic distances in Nelore, Gyr, Guzera, Caraco, Charolois, Canchim and Santa Gertrudis cattle. Genetics and Molecular Biology 1999, 22:539-54I.

27. Sambrook J, Fritsch EF, Maniatis T: Molecular cloning: A laboratory manual. In Cold Spring Harbour 3rd edition. Cold Spring Laboratory Press, New York; 1989.

28. Lien S, Rogne S, Brovold MJ, Lestrom A: A method of isolation of DNA from frozen semen (AI) bull semen. Journal of Animal Breeding Genetics 1990, 107:74.

29. Medrano JF, Aquilar-Cordova G: Polymerase chain reaction amplification of bovine $\beta$-lactoglobulin genomic sequences and identification of genetic variants by RFLP analysis. Animal Biotechnology 1990, I:73-74.

30. Sambrook J, Russell DW: Molecular cloning: A laboratory manual. In Cold Spring Harbour 3rd edition. Cold Spring Laboratory Press, New York; 200I

31. Tomar SS: Text book of population genetics. In Qualitative inheritance Volume I. first edition. Universal publication centre, Karnal, India; 1996. 